\title{
Financial Strategies and Profitability in Real Estate Companies
}

\author{
Rodrigo Gámez Pitre" ${ }^{*}$, Carlos Robles-Julio' and Geomar Molina-Bolívar² \\ 1Universidad de La Guajira, Riohacha, Colombia; rgamez@uniguajira.edu.co, croblesjulio@uniguajira.edu.co \\ ${ }^{2}$ Grupo de Investigación BIEMARC, Universidad de La Guajira, Riohacha, Colombia; gmolina@uniguajira.edu.co
}

\begin{abstract}
Objective: To determine the relationship between financial strategies and profitability in real estate companies in the municipality of Maracaibo, Venezuela. Materials and Methods: An analysis was applied descriptive, non-experimental, in the population under study, using a purposive sampling which covered four (4) selected companies, which were considered eight (8) reporting units (respondents). As an instrument of data collection was used a questionnaire composed of 72 items, with alternative answers with Likert-type scale, the same was validated by five (5) experts in the area of finance, with a high reliability of the coefficient of 0.94 Alfa-Cronbach. Finding: The results obtained during the investigation indicate that the real estate companies apply moderately, although in effectiveness financial strategies for the search for liquidity in the operations, but if you are identified with the measurement parameters to maintain the profitability of the business. Application: It was demonstrated that there is a high significant correlation ( $\mathrm{r}=0.83 ; \mathrm{P}=0.011)$ between both variables in the study.
\end{abstract}

Keywords: Financial Strategies, Profitability, Working Capital Investment

\section{Introduction}

The constant technological, economic and political change in the world, have led to companies in the search for various tools that allow to keep them in the market, where they seek to be every day more competent and the business to generate expected profits. In addition, the companies are looking to implement financial strategies that encourage new schemes of adaptability to changes in the world, being a reflection of the implementation of the strategies in the profitability of the business over time. However, there are companies with only one purpose, which is to generate dividends in time for shareholders, so that evaluations constants in the business dynamics require management to observe performance of the profits received by sales, being represented in the utility at the end of each year. The above, that management must proactively address operations between the different environments in which they live the organization in such a way as to consider the investment strategies, financing and the media in that profitability can be increased even more, through market research, sales and debt flow.

From the global financial crisis of the year 2007, constant economic changes were observed, with its epicentre the collapse of capital markets in the United States, which generated a bubble in the real estate markets, for reasons in the high liquidity of capital for investors in the housing sector, offering attractive interest banks for the acquisition of real estate credits, increasing the bond portfolio your portfolio so you can sell them to investment funds, pension funds and banks ${ }^{1}$.

According to the data provided by the Economic Commission for Latin America and the Caribbean and the United Nations (2), The Gross Domestic Product (GDP) in the global arena has been affected in a $81 \%$. It starts a process of recession in the European and North

*Author for correspondence 
American markets, the countries of Latin America begin to affect an increase in the rate of inflation and decrease in imports. Coupled with the global crisis, a rise in the price of oil and raw materials such as copper ${ }^{2}$. Similarly, in his analysis of the global crisis in the capital markets, projected economic growth averaging around $6 \%$ for Latin America and the Caribbean, being able to be a bit higher for the countries of South America (2.5 - 2.8\%), which relied on an increase in the demand for goods exported by the Latin American regions to retrieve the absorption of international investment flow. These economic changes promote strategies by the Latin countries to modify certain economic and fiscal policies to evade the economic meltdown that was presented at the global level.

With regard to Venezuela, the world economic situation affected on a large scale; likewise, there was a process of controls in its economy, which did not allow stimulating capital transactions between the productive sectors. Similarly, the rise of oil prices, stalled the inflationary process, according to figures published by the Central Bank of Venezuela (Banco Central de Venezuela) (BCV) by the end of 2009 the inflation rate $25.1 \%$ closed, representing 5.8 percentage points below that observed in the $2008^{3}$. Despite the results published by BCV not generated an atmosphere of reliability for the productive apparatus by the different policies issued by the government.

The shortage of supplies, devaluation of the currency and new labour standards, as well as the trade union violence has resulted in the construction sector has contracted in Venezuela. The BCV indicated in June 2015 that the construction sector suffered a fall of $20.2 \%$, mainly due to the difficulties to access basic inputs, such as the cement and steel products, wood, glass, ceramics, cables ${ }^{4}$. With the creation of the decrease in supply of immovable property, the real estate sector begins to perceive the effects of the declining economy. Under the raised, it begins to witness the decline in profitability in the real estate business due to lack of financial resources, as well as, the decline in the sectors of real estate on the primary markets, bringing with it the undertaking of market strategies or diversification of services to keep in the sector and remain an attractive business despite the different rules or laws that dictates the national government. Currently, there is a real estate market with high supply of immovable property, but low demand. The primary market has significantly declined due to lack of inputs for the construction, leaving the sector with secondary clients and to lease. As the market controlled by buyers and sellers of a particular good or service, determinants of supply and demand ${ }^{5}$, obviously this market is affected by the lack of plaintiffs in the Venezuelan real estate sector.

The low demand for individuals to purchase a home is caused by high inflation and the decline in the purchasing power of the citizen, coupled with the dollarization of the estate by the lack of support in the currency of Venezuela. According to the figures provided by the BCV, inflation was at $180 \%$ for December of the year $2015^{4}$. There is a considerable increase in real estate prices, the mechanisms implemented by the government for obtaining housing, they cease to be an option as it would be the processing of a mortgage housing policy law or own resources, which do not cover the total price of sale of a property. This is leading companies to frame financial strategies to maintain the support of their activities, without impairing the usefulness or liquidity, it is important to consider the value of investment to continue increasing its capital.It should be noted that the right approach of the financial strategy will allow the sector to survive in the market despite the political, economic and social players. These agents are limited to the investor to place their capital in property, which take root consequences not attractive in a given time. The stronger the financial performance and position in the market of the company, it is likely that count with a well-conceived and executed strategy ${ }^{\underline{6}}$.

To continue the problem arriving at a point where the intermediaries or enterprises, they will disappear by the lack of profitability. According to the consequences exposed, not to exist in the real estate market, it is necessary to evaluate the different scenarios in order to maintain the sector in the time, being imminent generate financial indicators that foster economic stability. The above-mentioned situation can generate insolvency, which will stay, in the time will translate in the closure or breakdown of the majority of companies in this sector. In addition to the raised, those companies that do not have the capacity to adapt to the requirements of the environment and implement financial strategies that allow them to foster greater profitability in the business, will be forced to close the doors of your business permanently, at the same time, affect the increase in the rate of unemployment in the Venezuelan State, in such a sense the need arises to give response to the problem.

This research is justified on the basis of that companies in the sector are a source of direct and indirect jobs in 
the country, and manage a diagnosis for its improvement will be providing information in line for decision making. There are studies that have shown how efficient financial strategies allow for greater profitability in different economic areas, such as small and medium-sized enterprises (PYMES) ${ }^{7}$, profitability of investment funds $s^{8}$, among others, as well as also stresses that the profitability is highly related to the current assets and investment ${ }^{2}$. In view of the foregoing was raised as an objective to characterize the financial strategies and profitability in the real estate companies in the city of Maracaibo, Zulia state, Venezuela, since it is one of the cities where you can find the main companies in the real estate industry in this country.

\section{Materials and Methods}

During the first half of the year 2016 a descriptive research and non-experimental, on a sample of four (4) real estate companies in the city of Maracaibo (REMAX RA, Century 21, El Rosal Bienes Raíces, y REMAX Victory), Which is made up of a total of 40 companies, according to the records of the Zulia state real estate chamber. The study was based on the analysis of financial strategies, by means of working capital (current assets Current liabilities), sources of funding (short term and long term) and Investment Strategies (evaluation of investment and investment in financial assets); as well as the profitability was studied from the perspective of the economic profitability (liquidity reasons and indices of activity) and the financial profitability (market reasons and indebtedness).

We used eight (8) reporting units belonging to the general management, administrative or financial companies selected (two from each one of them) to which was applied a survey using a questionnaire composed of 63 items, in order to establish a system of measurement of Likert scale, where the response categories were always (S), almost always (CS), Sometimes (AV), almost never $(\mathrm{CN})$ and never $(\mathrm{N})$, with a quantitative weighting of five (5), four (4), three (3), two (2), and one (1) respectively. By means of this scale was made the categorization of variables, by means of the range resulting in every aspect to study, whose categories were very effective $(5-4.2)$, effective (4.19 - 3.4), moderately effective (3.39 - 2.6), ineffective $(2.59-1.80)$ and very ineffective $(1.79-1)^{10}$. The instrument was validated by the trial of five (5) recognized experts, with expertise in the area of finance, as well as its reliability was determined through a pilot test, to which I have applied the Alfa-Cronbach coefficient, which resulted in a value of 0.94 that is considered very high reliability ${ }^{10}$.The data were analyzed by means of descriptive statistics, specifically averages, as well as absolute frequency (n) and relative (\%). In addition, a Spearman's correlation coefficient to observe if there is a relationship between financial strategies and profitability in the real estate industry in the city of Maracaibo, Venezuela; this was done with the program SPSS Statistics 24.0.

\section{Results and Discussion}

\subsection{Financial Strategies}

From this perspective, respondents claim in a $33.3 \%$ that only sometimes apply the mechanisms associated to stimulate current assets, while $22.2 \%$ said that I almost never performed, being the two most frequent responses, placing this indicator with an average of 2.79 in the category of moderately effective (Table 1). For their part, the respondents say in a $43.8 \%$ than ever establish conditions that favour the good management of the activities associated to the current liabilities, followed by the option almost never with $22.9 \%$ of respondents, situating itself in a category of ineffective with an average of 1.38 (Table 1).

Within the results obtained can be evidenced in the dimension of working capital that within the study population, $28.8 \%$ never make use of modalities of financing to the company by the constant fluctuation in the economy of Venezuela, 23.4\% sometimes seek to obtain liquidity through the use of cash, as well as accounts receivable to enhance return on investments; $22.6 \%$ almost never is oriented in obtaining loans made to third parties to be cancelled with a some service or cash, while $13.2 \%$ almost always happens the occurrence of the elements raised and $12 \%$ of respondents always try to apply it. The arithmetic mean of the working capital was on average 2.08 categorized as ineffective (Table 1). This shows that the real estate companies make little use of the tools offered as working capital to maintain operations and achieving a proper balance in the financial area, without increasing the risk and to reduce the profitability of the company.

On the basis of the ideas, does not coincide with the expressed where it stands out, that the difference between the current assets and current liabilities is a measure in the financial field, which seeks to protect the company from liquidity problems $s^{11}$. We are looking for a proper management between the accounts receivable and the financing of the company, if this is not well managed, decision-making 
Table 1. Absolute frequency (n) and relative(\%) of the indicators and dimensions associated with the variable financial strategies

\begin{tabular}{|c|c|c|c|c|c|c|c|}
\hline & $\mathbf{S}$ & CS & AV & $\mathrm{CN}$ & $\mathbf{N}$ & & \\
\hline & $\mathbf{n}(\%)$ & $\mathbf{n}(\%)$ & $\mathrm{n}(\%)$ & $\mathbf{n}(\%)$ & $\mathbf{n}(\%)$ & Media & Category \\
\hline Current assets & $1.33(16.7)$ & $1,11(13.9)$ & $2.67(33.3)$ & $1.78(22.2)$ & $1.11(13.9)$ & 2.79 & Moderately Effective \\
\hline Current Liabilities & $0.58(7.3)$ & $1,00(12.5)$ & $1.08(13.5)$ & $1.83(22.9)$ & $3.50(43.8)$ & 1.38 & Ineffective \\
\hline Working Capital & $0.96(12.0)$ & $1,06(13.2)$ & $1.88(23.4)$ & $1.81(22.6)$ & $2.31(28.8)$ & 2.08 & Ineffective \\
\hline Short Term & $1.08(13.5)$ & $0,75(9.4)$ & $1.00(12.5)$ & $2.58(32.3)$ & $2.58(32.3)$ & 2.40 & Moderately Effective \\
\hline Long Term & $3.00(37.5)$ & $1,00(12.5)$ & $0.67(8.3)$ & $1.56(19.4)$ & $1.78(22.2)$ & 3.24 & Moderately Effective \\
\hline Sources of Funding & $2.04(25.5)$ & $0,88(10.9)$ & $0.83(10.4)$ & $2.07(25.9)$ & $2.18(27.3)$ & 1.88 & Ineffective \\
\hline $\begin{array}{l}\text { Evaluation of } \\
\text { Investment }\end{array}$ & $2.42(30.2)$ & $2,25(28.1)$ & $0.42(5.2)$ & $0.83(10.4)$ & $2.08(26.1)$ & 3.26 & Moderately Effective \\
\hline Investments in assets & $0.0(0.0)$ & $0,0(0.0)$ & $0.0(0.0)$ & $1.83(22.9)$ & $6.17(77.1)$ & 1.23 & Very Ineffective \\
\hline Investment strategies & $1.21(15.1)$ & $1,13(14.1)$ & $0.21(2.6)$ & $1.33(16.7)$ & $4.13(51.6)$ & 1.50 & Very ineffective \\
\hline Financial Strategies & $1.40(17.5)$ & $1,02(12.7)$ & $0.97(12.2)$ & $1.74(21.7)$ & $2.87(35.9)$ & 1.82 & Ineffective \\
\hline
\end{tabular}

S: Always, CS: Almost always, AV: Sometimes, CN: Almost Never, N: Never

optimal decisions can be affected; at the same time, expose that the aim is to collect them as fast as possible, without loss of sales, due to collections quite aggressive mechanism to ensure the return of the money in a timely manner, thus avoiding loss in the usefulness of the company ${ }^{12}$.

The short-term financing a $64.6 \%$ of the respondents state than ever and hardly ever (32.3\% in each option) apply this type of funding (Table 1), such as placing an asset as security for the payment of the commitment, to borrow through bank loans and grant commercial credits on the basis of the services provided. On the other hand, in terms of long-term funding results indicate that a $37.5 \%$ always applies this type of financing, while a $22.2 \%$ affirms that never does, as well as a $19.4 \%$ expresses that almost never does, obtaining an average of 3.24 which puts it in the category of moderately effective (Table 1), this indicates that the companies have opted to manage the scheme of immediate cancellation in the services provided by the high fluctuation in inflation in the economy of Venezuela, caused by the devaluation of the currency, generating cut in the times to grant trade credits to customers, moreover, that these companies were formed by equity of shareholders, as well as the assets acquired in time, without recourse to financing mechanisms.

This means that firms manage their accounts payable in a moderate way so as not to fall into the lack of liquidity and thus, not failing to comply with the commitments made by the invoices received or credits applied by the organization. In relation to the above short-term loans tend to be seen as a form of self-assessment, as they bought goods generate sufficient cash flow to repay the loan, in particular, to cope with the financial accumulation seasonal in accounts receivable and inventory ${ }^{11}$. In this regard, it is noted that real estate companies are not annexed in the stock market to place the figure of commercial paper due to the existing controls on the Venezuelan economy, slowing the obtaining financial resources to revive with capital of the company's operations. As a result, it can be seen that the real estate companies in the city of Maracaibo, consider obtaining the financial products in the relevant entities for the cancellation of debt contracted in the time, without generating losses to business by the constant changes in the economy.

Within the results obtained can be evidenced in the dimension of funding sources that within the study population the $27.3 \%$ never are oriented in the implementation of financing, by the high quotas to cancel on a monthly basis into the respective entities. In the same order, the $25.9 \%$ almost never evaluated the periodicity of the cash flow to consider funding the operations through the provision of credit, accounts receivable or other, the $25.5 \%$ always considers the acquisition of long-term financing by the flexibility offered the product to make a commitment, while $10.9 \%$ almost always applies as evaluated in the study and $10.4 \%$ sometimes takes into account the profitability of short-term financing (Table 1). On the other hand, the arithmetic mean of the Sources of 
Financing of 1.88 categorizes this feature ineffective; this means that companies within its business structure do not evaluate the application of financings in the short or long term by the constant changes in the economy of the country. The same impact in: times of lack of liquidity to meet the daily commitments which may represent a high risk for the organization.

With regard to the evaluation of a $30.2 \%$ of investment respondents indicate that they always activities related to assessing the investment made, while $28.1 \%$ mentioned that almost always does so, followed by $26.1 \%$ which expresses that are never performed activities such as valuation of the rate of return, capital investment, net present value, among others, establishing an average value of 3.26 with a moderately effective category (Table 1 ). This means that the companies take into account the analysis carried out with the internal rate of return for investment in the market or, failing that, to assess the profitability of the project with the profits obtained in a given time.

The investments of assets showed a high percentage of respondents who say that they are never performed this type of investment with a $77.1 \%$, followed by the option almost never with a $22.9 \%$ for an average of 1.23 , indicating a category very ineffective for this indicator (Table 1), which is negative for investments in financial instruments that diversify the portfolio, at the same time, do not use the debt instrument to obtain liquidity. The above, there is little agreement, by those who express that investments in financial assets, unlike the titles of commercial values in the capital market, represent a long-term commitment of funds for the shareholders, which may include bonds, shares or investments in other operations; therefore, the companies studied are inefficient in this type of action ${ }^{13}$. The indicators at the level of the investment strategies show a greater percentage of respondents who expressed never (51.6\%) to apply these strategies and a $16.7 \%$ indicated that almost never, categorizing this dimension of very ineffective in the real estate companies in the city of Maracaibo (Table 1).

The commitment to the implementation of appropriate actions for the sustainability of the business on the financial aspects makes it necessary to consider multiple strategies that allow the enrichment and sustainability of the company in the time to achieve a better positioning in the market in the short, medium or long term. In this regard, it is noted that the $35.9 \%$ of the population surveyed in real estate companies, have stated that never have Financial Strategies in the market in order to extend the range of your financial portfolio, because of the high level of economic fluctuations and governmental policies that generate instability in the decision-making process to put their money into investments which will receive a return of the invested in short term. On the other hand, $21.7 \%$ almost never use sources of financing for self-financing debt or binding commitments to maintain operations. This is due to real estate companies are managed with third party funds in the provision of services and cash flow is not replaced immediately, which causes the risk of acquiring a commitment which is not able to cancel on time.

At the same time, the $17.5 \%$ of the companies in real estate always evaluate the possibility of the search for long-term financing sources that generate dividends more rapid for the cancellation of the debt purchased in order to prevent the loss of capital in short time. For its part, the $12.2 \%$ of the subjects consulted expressed sometimes make use of strategies of working capital, as a source of liquidity in the business to achieve an increase in profitability and risk reduction, achieving a higher valuation of the company (Table 1). In the meantime, the arithmetic mean total of the variable in relation to each of the dimensions laid down for analysis in real estate companies studied, corresponds to an average of 1.82 indicating that the aspects related to analyze the behaviour of financial strategies aimed at companies in the real estate sector of Maracaibo, present a level of implementation ineffective. The assessment of financial strategies in the business is very limited by real estate companies, perceiving a rejection in the search for solutions or alternatives that are having an impact on the growth of the company. This coupled with the country's economic problems, the lack of interest in the investment or obtaining financing to orient it in areas of interest, where the partners or shareholders receive acceptable performance for risk-taking that are present in the domestic market.

On the basis of the ideas, it is stressed that in the majority of PYMES of the trade sector of the municipality of Santiago Marino, Aragua state, Venezuela, lack a solid financial planning process, solution-oriented approaches to automation of resources, internal and external capabilities for a good administration, implementation of its financial strategies aimed at sustainability, as well as business growth ${ }^{\text {}}$.

\subsection{Profitableness}

The economic profitability through liquidity reasons indicates that a $45.8 \%$ almost always calculated the percentage of sales units after deduction of the expenses, 
the $33.3 \%$ always measure the ability of liquidity to cancel the obligations, while $16.7 \%$ never keeps the utility on sales to comply with their obligations in the short term. As a result, it was obtained a arithmetic average of 3.75 indicating a effective category (Table 2). This is evidence that real estate companies have knowledge in managing their liquidity at the end of each financial year monthly, quarterly or higher for the success of the company, based on the profits earned on sales. The liquidity of a company is measured by its capacity to meet its short-term obligations as they arrive to their maturities; these reasons develop early signs of cash-flow problems and failures of impending business ${ }^{12}$. It should be noted, must find a balance between the needs of security provided by the liquidity against low yields of liquid assets of shareholders.

On the other hand, according to the indices of activity showed that $41.7 \%$ always study how to optimize the sources of funds for obtaining liquidity, the $29.2 \%$ sometimes analyzed the profitability of assets to be financed independently, while the $25 \%$ almost always measure the speed with which various accounts are transformed into cash, and $4.2 \%$ almost never applies these activities. It was obtained an arithmetic average of 4.04 which is considered to be very effective in the category (Table 2). As a result, there is evidence a high application in to verify that the management of inflows and outflows of cash in your sales processes, which is reflected in the expenditure management and collections in ways that are balanced in the transactions of companies.

This is evidence of a measurement of the speed in how the various accounts are transformed into cash or sales, i.e. the inputs or outputs. In a nutshell, measure the efficiency or forms of each organization in a variety of dimensions, such as inventory management, expenses and charges ${ }^{12}$. The reasons for a market showed that $33.3 \%$ always have a clear measurement in the risk to determine the financial profitability, the $20.8 \%$ almost never measure the value of the market with respect to the current price of its actions, the $25 \%$ almost always evaluate the performance measurement to determine the financial profitability, the $8.3 \%$ sometimes applies a measurement of risk for the financial profitability, while $12.5 \%$ never uses it in their measurements (Table 2). As a result, it was obtained a arithmetic average of 3.46 Being Effective. Taking into account the above, real estate companies have a clear measurement of risk factors and performance offered by the market to meet the gain obtained after performing the sales. It should be noted, the knowledge of the possible risks to the environment, allows organizations to be prepared for the different changes in the industry, managing to keep the fruits projected in the year. The market value of a company, as measured by the market price for their actions, measures clearly the development of the company in terms of risk and return. Focuses its calculation on the gains and another takes into account the value of books ${ }^{12}$.

On the other hand, debt ratios show that $41.7 \%$ sometimes obtain liquidity or utility through the financing of fixed costs, the $29.2 \%$ never applies indebtedness on the basis of the money from other entities, while $20.8 \%$ almost always uses financing of fixed costs and the remaining $8.3 \%$ almost never applies it; it was obtained a

Table 2. Absolute frequency (n) and relative (\%) of the indicators and dimensions associated with the variable profitability

\begin{tabular}{llllllll}
\hline & $\mathbf{S}$ & $\mathbf{C S}$ & $\mathbf{A V}$ & $\mathbf{C N}$ & $\mathbf{N}$ & & \\
\cline { 2 - 6 } & $\mathbf{n}(\%)$ & $\mathbf{n}(\%)$ & $\mathbf{n}(\%)$ & $\mathbf{n}(\%)$ & $\mathbf{n}(\%)$ & Media & Category \\
\hline Liquidity Reasons & $2.67(33.3)$ & $3.67(45.8)$ & $0.0(0)$ & $0.33(4.2)$ & $1.33(16.7)$ & 3.75 & Effective \\
Indices of Activity & $3.33(41.7)$ & $2.00(25.0)$ & $2.33(29.2)$ & $0.33(4.2)$ & $0.0(0.0)$ & 4.04 & Effective \\
\hline $\begin{array}{l}\text { Economic } \\
\text { profitability }\end{array}$ & $\mathbf{3 . 0 0 ( 3 7 . 5 )}$ & $\mathbf{2 . 8 4 ( 3 5 . 4 )}$ & $\mathbf{1 . 1 7 ( 1 4 . 6 )}$ & $\mathbf{0 . 3 3 ( 4 . 2 )}$ & $\mathbf{0 . 6 7}(\mathbf{8 . 3})$ & $\mathbf{3 . 9 0}$ & Effective \\
\hline $\begin{array}{l}\text { Market Reasons } \\
\text { Debt Ratios }\end{array}$ & $2.67(33.3)$ & $2.00(25.0)$ & $0.67(8.3)$ & $1.67(20.8)$ & $1.00(12.5)$ & 3.46 & Effective \\
\hline $\begin{array}{l}\text { Financial } \\
\text { Profitability }\end{array}$ & $0.00(0.0)$ & $1.67(20.8)$ & $3.33(41.7)$ & $0.67(8.3)$ & $2.33(29.2)$ & 2.54 & Ineffective \\
\hline Profitability & $\mathbf{1 . 3 4 ( 1 6 . 7 )}$ & $\mathbf{1 . 8 4 ( 2 2 . 9 )}$ & $\mathbf{2 . 0 0 ( 2 5 . 0 )}$ & $\mathbf{1 . 1 7 ( 1 4 . 6 )}$ & $\mathbf{1 . 6 7}(\mathbf{2 0 . 8})$ & $\mathbf{3 . 0}$ & $\begin{array}{l}\text { Moderately } \\
\text { Effective }\end{array}$ \\
\hline
\end{tabular}

S: Always, CS: Almost always, AV: Sometimes, CN: Almost Never, N: Never 
arithmetic average of 2.54 being ineffective (Table 2). The above allows you to analyze that real estate companies do not make use of tools of indebtedness with the fixed commitments to circulate the capital, for the benefit of the increase of the usefulness of the company. The use of these measures if they are not performed adequately not can influence an increase of financial leverage. The position of indebtedness of a company referred to in the amount of money (of others) used to generate profits. Therefore, when the greater the amount of debt purchased by the company in relation to its total assets, the greater the financial leverage, which is associated with increased risk or performance through the use of funding of fixed costs as debt or preferred shares $\frac{12}{}$; to be real estate companies of Maracaibo ineffective in these actions, their profitability can be affected from this approach.

The variable profitability gained an average of 3.45 considered effective (Table 2), this means that the companies studied considered factors associated with the assessments of the cash flow and the form such as sales or the mobility of service makes each day more lucrative business in order to be able to survive in time. On the other hand, it strengthens in components in the sector of the market to raise strategies, which will make it possible to increase the profitability of the business without taking into account the leverage, cash handling is subject to third-party funds. You must manage the behaviour of economic fluctuations, as well as the country's policies to take measures or decisions, which are considered effective or efficient by management or leadership of the organization. The performance measures the effectiveness of the investment on the available assets, that is, the higher the return on total assets, it is considered best investment for shareholders, calculated by the ratio of profits ${ }^{12}$, following this idea, the real estate sector still remains profitable in the city of Maracaibo.

\subsection{Financial Strategies - Performance Relationship}

The Spearman correlation analysis revealed that there is a direct correlation between the variables studied $(\mathrm{n}=8 ; \mathrm{r}=0.83 ; \mathrm{P}=0.011)$, indicating a close relationship between investment, assets, cash flow and profitability in the real estate companies in Maracaibo, Venezuela; even when strategies are in a category ineffective and profitability in a category Effective, when strategies increased its value, rents also did, which is a trend in economic systems 9 .

\section{Conclusion}

Companies in the real estate sector of Maracaibo, employ financial strategies related to components belonging to the working capital, where paid dividends is quick and timely in order to be able to assume the commitments, very little guide to sources of short-term financing to be able to cancel the debts or refinance the obligations, allowing to maintain operations at the time. In that case, are oriented in the pursuit of long-term financing which generate dividends without compromising any assets of the company, as a result, you can direct funds for investments in other sectors of the market that are measured, succeed in obtaining financial resources quickly, which allow the assessments for the viability of the business. Profitability in the large market of real estate, allows you to maintain the flow of sales of movable form on a large scale, allowing generating income short time continuous or long-term.

The variables studied showed a very high degree of association; whereas the values increase of financial strategies, gradually increase the values of profitability. It is recommended to the extent possible; according to the policy of each company apply a balanced policy in the management of the assets and liabilities of the company, for obtaining funding through the use of third-party funds, which in turn would allow obtaining more liquidity. At the same time, find ways to capitalize on retained earnings to give greater reliability to the transactions. The real estate companies should guide their actions in pursuit of short-term borrowing. The economic system controlled and interest rates charged by banks, do not allow them to be tossed to and fro to assume the commitment of payment. Therefore, it is feasible to obtaining a loan, line of credit or other, for funding operations, being the Bolivar a coin in constant devaluation by economic problems in Venezuela; therefore it is recommended that ongoing evaluation of profitability and even of the possible future financial strategies to implement.

\section{Reference}

1. Torrero Ma-as A. La crisis financiera y sus efectos sobre la economía espa-ola. Instituto Universitario de Análisis Económico \& Universidad de Alcalá; 2010. p. 1-27. 
2. CEPAL. La crisis financiera internacional y sus repercusiones en América Latina y el Caribe. Naciones Unidas; Impreso en Naciones Unidas; 2012. p. 1-47.

3. CEPAL. República Bolivariana De Venezuela. Estudio Económico de América Latina y el Caribe. Comisión Económica para América Latina y el Caribe (CEPAL); 2017. p. 1-7.

4. BCV: Inflación acumulada de 2015 cerró en $180,9 \%$ y PIB se contrajo un 5.7\%. Date accessed: 18.02.2016. https://www.panorama.com.ve/politicayeconomia/ BCV-Inflacion-acumulada-de-2015-cerro-en-1809-y-PIBse-contrajo-un-57-20160218-0014.html.

5. Mankiw GN. Principios de economía, 6a Edición. Ediciones Paraninfo; 2012. p. 1-888.

6. Thompson HE. Regulatory Finance: Financial foundations of rate of return regulation. 1st Edition. Springer; 2012.

7. Flores Naranjo NV. Estrategias financieras aplicadas al proceso de sostenibilidad y crecimiento de las PYME del sector comercio del Municipio Santiago Mari-o del Estado Aragua. [Carabobo, Venezuela]: Universidad de Carabobo; 2015.
8. Byrne Mrsich M. Efectos de la rentabilidad en los fondos de inversión de las AFP en el Perú en tiempos de crisis financiera y su incidencia en los fondos de pensiones de los afiliados. [Peru]: Universidad de Sarmiento de Porres; 2014.

9. Altuve J. Rentabilidad de la variable activo corriente o circulante, Actualidad Contable Faces. 2014; 17(29):5-17.

10. Hernández Sampieri R, Fernández Collado C, Baptista Lucio P. Metodología de la investigación. 6a Edición. Editorial Mc Graw Hill. México; 2014.

11. Van Horne JC, Wachowicz JM, González Osuna MA. Fundamen tos de administración financiera. México: Pearson Educación; 2010. p. 1-746.

12. Gitman L, Zutter C. Principios de Administración Financiera Decimosegunda Edición. Pearson Educación, México; 2012. p. 1-720.

13. Block S, Hirt G. Administración financiera. 11a Edición. McGraw-Hill Interamericana; 2005. p. 1-653. PMid: 16400797. 